\title{
A pilot assessment: Integrating a cystic fibrosis simulation scenario to enhance pre-licensure educational understanding of genomics
}

\author{
Leighsa Sharoff* \\ Hunter College, United States
}

Received: April 11, 2019

DOI: $10.5430 /$ jnep.v10n1p24
Accepted: September 3, 2019 Online Published: September 18, 2019

URL: https://doi.org/10.5430/jnep.v10n1p24

\begin{abstract}
Background and objective: Integration of patient simulations into the nursing student curricula have been shown to be effective and innovative teaching enhancements leading to enhanced knowledge, clinical reasoning and judgment for students, whilst promoting optimal patient care. This pilot study aimed to explore how the use of a simulation, with a genetic component of a Cystic Fibrosis $(\mathrm{CF})$ case scenario, improved the self-perceived knowledge comprehension of pre-licensure baccalaureate nursing students of a large diverse urban School of Nursing.

Methods: Three assessment surveys were utilized to glean data: nine multiple choice questions explored factual content of CF pre/post simulation; five question survey explored self-perception of knowledge and one open-ended simplified critical incident report provided qualitative data.

Results: Twenty-four pre-licensure third year nursing students participated (three groups of eight students). All participants agreed that their understanding of the genetic component of $\mathrm{CF}$ improved post simulation. Four major themes emerged from the qualitative data: genomics and nursing; patient education; teamwork exercise and patient-nurse relationship.

Conclusions: Integrating a genetically-based condition into a simulation, whereby students are expected to research the condition, engage in patient education, facilitate effective and appropriate nursing care enriches their critical thinking, confidence, skills and knowledge acquisition.
\end{abstract}

Key Words: Cystic fibrosis, Simulation, Patient education, Genomics

\section{BACKGROUND}

Genetically-based healthcare has exponentially transformed the landscape. In order to meet this new learning need, nurse educators need to be innovative and creative with integrating this required core competency into curricula. Cystic Fibrosis (CF) is one condition that can be adapted into simulations to enhance students' overall knowledge base while promoting safe and effective personalized patient care practice. Nurses have an essential role in conveying genomics and precision medicine advances and advantages to everyday health care. ${ }^{[1]}$ Preparing the next generation of practitioners in the genomic era demands educators to explore new pedagogical strategies for academic inclusion. Nurse educators not only need to educate themselves on genetic literacy, but with an already constrained nursing curricula, educationalists should also be progressive and inventive in how to enhance their students' genetic knowledge. ${ }^{[2]}$

*Correspondence: Leighsa Sharoff; Email: 1sharoff@ hunter.cuny.edu; Address: Hunter College, United States. 


\subsection{Simulation}

The realism of simulation provides clinical setting opportunities for undergraduate pre-licensure nursing students to experience medical/nursing situations. Simulation has been researched and evidence has demonstrated it has an influential impact on pre-licensure nursing education. ${ }^{[3-6]}$ It has been an effective pedagogical teaching tool in a variety of nursing topics, such as knowledge and self-competence; ${ }^{[7]}$ caring for victims of elder abuse and intimate partner violence $;{ }^{[8]}$ nursing ethics principles $;{ }^{[9]}$ end of life care attitudes ${ }^{[10]}$ and caring for a patient with sickle cell anemia. ${ }^{[11]}$ Educational opportunities that provide a variety of technological informatics skills, including simulation, are necessities in today's academic environment. ${ }^{[12]}$

Simulation-based learning experiences (SBLE) has been shown to provide safe realistic clinical environments, providing students with experiential diverse learning opportunities, while encouraging active learning. Augmenting nursing curricula through simulation has led to enhanced knowledge, clinical reasoning and judgment while promoting optimal patient care. ${ }^{[13,14]}$ It has become customary for pre-licensure curricula to expand experiential learning outcomes through simulation, whereby students can apply their theoretical knowledge and skills in a safe learning environment. ${ }^{[15]}$

Enhancement of medical/nursing conditions and complications, critical thinking and reasoning and skill performance are cohesively united within the learning process through an interactive patient simulated scenario. ${ }^{[13-16]}$ Yet integrating a simulation with a genomic component has not been fully explored though it is an excellent educational opportunity. Only one study has demonstrated the benefit of a deliberate inclusion of a genomic integration into a nursing simulation. ${ }^{[11]}$ Online simulation learning modules to assess nurses working in patient care with CF patients demonstrated positive outcomes. ${ }^{[17]}$ Prenatal genetic counseling scenarios utilizing high-fidelity conversion simulations confirmed simulation effectiveness as a teaching pedagogy for pregnancy care. ${ }^{[18]}$ Physician assistant students utilized standardized patients to improve their perceived genomic comprehension as well as internet-based online learning strategies for interviewing skills. ${ }^{[19,20]}$ Internet-based educational programs have routinely achieved positive learning outcomes for geneticallybased education. ${ }^{[21]}$

Enhancing students' opportunities to improve their patient care interactions, patient safety measures and task confidence, analytical thinking skills and clinical judgment/reasoning, communication practices and supportive techniques are just a few of the highlights to SBLE. Simulation increases clinical confidence resulting in improved patient care and clinical out- comes as well as knowledge and self-perceived abilities. ${ }^{[3,7]}$ As nurses tacitly understand patients' concerns and problems, they can engage in the healing-caring process with concerned participation. ${ }^{[22]}$ And as students become more clinically aware, they can be more reflective of their participation in the learning process. Enriching students' comprehension through simulation affords educators opportunities to include dynamic learner-centered pedagogical methodologies ensuring students learning outcomes. ${ }^{[23]}$

\subsection{Genomics}

Genomic knowledge is a required competency for all nurses and nursing students as identified by the Essentials of Genetic and Genomic Nursing: Competencies Curricula Guidelines, and Outcome Indicators. ${ }^{[24]}$ As a first step to this integration process, current knowledge and comfort with nursing students' exposure needs to be explored to identify their level of knowledge, skills and attitudes. Genomics is the study of the structure and function of the genome and its interactions with the environment whereas the study of inheritance and variation is genetics. ${ }^{[19]}$ Genomic advancements require the healthcare workforce to be informed and educated, with the ability to empower the patient and their family with knowledge and education. Genetically-based healthcare is a worldwide consideration, yet considerable evidence has shown that nurses overall lack confidence and competency in this area, and dispensing genomic education is erratic and variable. ${ }^{[25-27]}$ Genomics relevance is correlated to health overall, including risks and indicators of disease, therapeutic actions and decisions, advancement of new therapies, and responses to treatment interventions. ${ }^{[1]}$ Nurses need to be confident in their ability to comprehend this science, advocate, elucidate information, support and educate patients and their families through their lifespan. ${ }^{[28]}$ The translation of academic knowledge to bedside care begins with nurse educators successfully implementing novel singular experiential opportunities for the student to incorporate the tacit actual and self-perceived knowledge into their professional personhood.

\subsection{Cystic fibrosis}

$\mathrm{CF}$ is an autosomal recessive disorder, which meaning that each time two carriers of the disease conceive, there is a 25 percent chance of passing $\mathrm{CF}$ to their children; a 50 percent chance that the child will be a carrier of the CF gene; and a 25 percent chance that the child will be a non-carrier. ${ }^{[29]} \mathrm{CF}$ incidence varies globally, being severely underdiagnosed in Asia, 1 in 2,000-3,000 newborns in European Union and 1 in 3500 in the USA found to be affected. ${ }^{[30]}$ A recent review of the literature (1938-2017) found a higher frequency of registered CF patients in the European Union. ${ }^{[30]}$ It is es- 
timated that there are between 70,000 and 100,000 people with CF worldwide. ${ }^{[31]}$ There is a crucial necessity to revitalize national and global $\mathrm{CF}$ registration, as most countries do not have registries or collect data from healthcare facilities. ${ }^{[30]}$ Even with irregular reports from Asian and African countries, it is estimated that $\mathrm{CF}$ affects approximately 1 in 17,000 African Americans, 1 in 31,000 Asian Americans and South America as a continent has a high distribution of $\mathrm{CF}$ patients. $^{[30,32]}$

$\mathrm{CF}$ affects the respiratory, digestive and reproductive systems involving the production of abnormally thick mucus. ${ }^{[12]}$ It is caused by mutations in a gene, with over 2000 variants that occurs in the $\mathrm{CF}$ transmembrane conductance regulator (CFTR) gene, which is located on chromosome 7q31.2. ${ }^{[30-33]}$ Simplistically, the CFTR gene is a membrane protein and chloride channel that receives instructions to transport chloride and thiocyanate ions in and out of the epithelial cells. Due to a variant in the CFTR gene, the chloride ions cannot properly regulate the flow, leading to abnormally high levels of thickened mucous is formed in the lung, pancreas, reproductive and digestive system. ${ }^{[30,33]}$ The most common CFTR variant is Delta F508, leading to an accumulation of thickened mucus in exocrine- and exocrine-associated organs. ${ }^{[30,33]}$ The scope, severity and complications of CF are due to polymorphisms in CFTR gene, are highly mutable in different populations and severity varies significantly from person to person regardless of age. ${ }^{[29,30,34]}$ Individuals with CF have a variety of symptoms including very salty-tasting skin, persistent coughing and lung infections, constant thick mucus in the lungs and digestive tract leading to difficulty breathing and digesting food further compromising weight gain. ${ }^{[29,30,33]}$ This is especially difficult for a newborn, as it can lead to failure to thrive. ${ }^{[33]}$ There is no cure for CF, unfortunately deterioration is inevitable, leading to debility and eventually demise. ${ }^{[29,33]}$ Initial diagnosis is usually made in early infancy, median age of survival has been 33.4 years and with current treatment options, many people now live into their fifties and sixties. ${ }^{[29]}$

\subsection{Aim}

This pilot study aimed to explore how the use of a simulation, with a genetic component of a CF case scenario, improved the self-perceived knowledge comprehension of pre-licensure baccalaureate nursing students. This pilot assessment utilized identical pre and post surveys. Integrating a genomic component to a simulation, development of a genetic scenario and exploring students' perceptions of their genomic knowledge pre and post the simulation experience will be discussed.

\section{Method}

Three assessment surveys were utilized to glean data: nine multiple choice questions explored factual content of $\mathrm{CF}$ pre/post simulation experience; a five-question survey explored self-perception of knowledge post simulation and one open-ended simplified critical incident report provided additional qualitative data. Institutional Review Board (IRB) approval was obtained for data collection during Fall 2018. Completing the anonymous surveys denoted consent.

\subsection{Design/participants}

Identical pre/post assessment survey design was deplored examining students understanding of $\mathrm{CF}$ prior to their scheduled simulation (pre-conference) and directly after their simulation (post-conference). One highly experienced senior nurse clinical educator was scheduled for three separate clinical groups. After speaking to this educator, it was decided that these three groups would be purposefully assigned the new CF simulation scenario. The researcher specifically chose this educator due to her pediatric expertise, having three separate clinical groups and her willingness to provide feedback for revisions to the scenario after each experience. All three clinical groups were third year (junior level) prelicensure baccalaureate nursing students who were required to attend clinical as part of the overall nursing curriculum. Simulation case scenarios are written to coordinate to students' educational knowledge level and abilities. ${ }^{[23]}$ A total of 24 students participated (females $=21$; males $=3$; mean age 21.5), as shown in Table 1 Demographics. The purposeful sampling of these 24 participants were all eligible to voluntarily participant as they were all assigned to this senior clinical nurse educator. There was no recruitment of participants as they were preassigned to this nurse educator. All simulations were conducted at the School of Nursing's (SON) Simulation Center.

Table 1. Demographics

\begin{tabular}{llllll}
\hline Group & n & Males & Females & Age Range & Mean Age \\
\hline A & 8 & 1 & 7 & $20-26$ & 21 \\
B & 9 & 1 & 8 & $*$ & $*$ \\
C & 7 & 1 & 6 & $20-29$ & 22 \\
Total & 24 & 3 & 21 & $20-29$ & 21.5 \\
\hline
\end{tabular}

\subsection{Simulated scenario utilized}

The researcher is the Simulation Coordinator at a diverse urban SON in the United States as well as the main genomics didactic educator for the SON. The investigator routinely explores contemporary and modern strategies to further enhance students' educational understanding of genomics and caring for patients through their lifespan with genetically- 
based conditions. The researcher develops all factitious simulation scenarios for the SON and has developed specific pre-briefing preparatory material to guide the educator and student to achieve the desired learning outcomes. ${ }^{[11,23,35]}$ The researcher develops all pre-briefing preparatory material for clinical educators and students. The students pre-briefing preparatory material provides the simulation scenario, including medications with pertinent laboratory data, and learning objectives. The clinical educators receive a detailed prebriefing preparatory material, including all the students' content with additional material pertaining to nursing implications, and debriefing questions. ${ }^{[11,23,35]}$ In addition, the educator's material includes pathophysiologic mechanisms and complications pertaining to $\mathrm{CF}$, numerous treatment options, including gene therapy, images of pulmonary and digestive systems in patients with $\mathrm{CF}$, and comprehensive information on the debriefing process. ${ }^{[23]}$

The researcher was an early adopter and developer of simulation at the SON and designed the experience to closely resemble a clinical day. Thus, the nurse educator holds a preconference prior to the simulation, discussing the assigned scenario and evidence-based research articles the students are required to bring to the simulation. The post-conference is an opportunity for the clinical group to explore the main learning outcomes of the experience.

\subsection{Assessment of self-perceived genetic knowledge sur- veys}

\subsubsection{Pre and post simulation assessment survey}

The identical pre/post simulation assessment survey was initially a ten-question survey was based on information from the University of Rochester Medical Center Health Encyclopedia: What Do You Know About CF ${ }^{[36]}$ This multiplechoice assessment asks basic information regarding CF. Prior to utilizing, the researcher shared this assessment with the experienced nurse clinician, and it was agreed that nine questions would be utilized for this study. The rationale for removing one question was the expert clinician felt that the students would be confused by this one question and she would discuss this question during the debriefing process of the simulation. Basic questions ranged from genetic information pertaining to $\mathrm{CF}$; how $\mathrm{CF}$ affects the body and symptoms; what happens to the mucus glands and digestive system; how CF is diagnosed, treatment options and who is at most risk. Data was based on percentages of correct responses for both assessments.

\subsubsection{Students' perceptions of genomic knowledge after simulation}

This survey was based on another study conducted by the researcher, which explored genomic knowledge after a sim-

Published by Sciedu Press ulation based on a patient with sickle cell disease. ${ }^{[11]}$ The investigator adapted this 5-question self-perceived knowledge to the $\mathrm{CF}$ scenario, exploring students perceived genetic knowledge post simulation; their understanding of $\mathrm{CF}$ genetic component; ability to educate patient/family about $\mathrm{CF}$; their perceived $\mathrm{CF}$ understanding to provide appropriate nursing care and interventions; their critical thinking and clinical judgment providing CF genetic information. This survey used a licker scale of 1 to 4 , ranging from strongly agree/1 to strongly disagree/4.

\subsubsection{One open-ended simplified critical incident}

This open-ended simplified critical incident statement asked participants to explore "do you feel that this scenario enhanced your overall ability to integrate genomics into your knowledge base of nursing and nursing care? This provided a qualitative aspect to the quantitative data.

\subsection{Simulation intervention process with the CF sce- nario}

Minimizing coercion and ethical consideration for the participants was paramount for this pilot study. The investigator was not present during the simulation. The senior simulation technologist was instructed to leave the surveys packets (comprised of the consent/information sheet, pre/post assessments, students' perception of their knowledge after simulation and the one open-ended critical incident statement with room for participants to write their response) on the conference table in the room where the pre/post conferences were held. An IRB-approved script was read by the senior simulation technologist, providing participants with instruction to pick up the surveys if they wish to be included in this study. There were no personal identifiers collected except for gender and age. The participants were instructed to leave the completed surveys packets on the conference table, to not put their names or initials on the packet and they would be collected by the senior technologist and placed in a sealed envelope. There was no conflict of interest or participant bias by the technologist, who was not involved in the grading of the didactic course or any aspect of the simulation (which was not graded). The researcher picked up the sealed envelope after all students left the simulation environment.

\subsection{Statistical analysis}

Data were coded and entered into an SPSS database by the researcher. Percentage of correct responses and participant frequencies with standard deviation was inputted into a table summarizing pre and post responses individually. Students' perceptions of their genomic knowledge after simulation survey was analyzed according to licker scale responses. Data to the one open-ended qualitative question was analyzed, 
and thematic interpretation of commonalities emerged with theme clustering. This data was managed in an objective and systematic approach leading to the construction of correlating suppositions.

\section{RESUlts}

Twenty-four pre-licensure third year nursing students participated (three groups of eight students) and all agreed that their understanding of the genetic component of CF improved post simulation.

\subsection{Pre and post simulation assessment survey}

Of the nine questions in the identical pre/post survey, five questions had $100 \%$ correct responses for all three groups on the post assessment survey: CF affects which body system; which symptoms in an infant/child might indicate CF; what happens to mucus glands; who is at most risk and treatment medication options. This demonstrates an improvement from the pre-simulation assessment of CF knowledge. Three questions showed improvement in correct responses post simulation, which included how digestive system is affected by excess mucus (one student incorrect response pre-assessment [n $=23$ correct $]$ to $100 \%$ correct post-assessment); how CF diagnosed (6 students incorrect response pre-assessment [n $=18$ correct $]$ to $91.70 \%$ correct $[\mathrm{n}=22]$ post-assessment) and the abnormality results in an imbalance to which key body substance ( 7 incorrect responses pre-assessment $[\mathrm{n}=$ 17 correct $/ 75 \%$ ] to $n=21$ correct [87.50\%] post-assessment. One question (how $\mathrm{CF}$ is passed down through families) had $n=19$ correct pre-assessment $(83.3 \%)$ to $n=21$ correct $(87.5 \%)$ post-assessment. Yet this question had one participant in post-assessment decline in one group's correct response; meaning pre-assessment Group A had 75\% correct $(n=6)$ to Group A post-assessment $n=5(62.5 \%)$. As data was deidentified, there was no way to determine which participant this was, however, the correct answers to this survey was discussed during the post-conference. Inclusively, majority of data suggests the genomic component of the simulation enhanced students' understanding of CF. Table 2 provides data on Pre/Post Assessment of CF Simulation Scenario [Percentage of Correct Responses].

Table 2. Pre/post assessment of CF simulation scenario [Percentage of correct responses]

\begin{tabular}{|c|c|c|c|c|c|c|c|c|c|c|}
\hline \multirow{3}{*}{ Question } & \multirow{2}{*}{\multicolumn{4}{|c|}{$\begin{array}{l}\text { Pre Simulation } \\
\text { Student Groups }\end{array}$}} & \multirow{3}{*}{ SD } & \multirow{2}{*}{\multicolumn{4}{|c|}{$\begin{array}{l}\text { Post Simulation } \\
\text { Student Groups }\end{array}$}} & \multirow{3}{*}{ SD } \\
\hline & & & & & & & & & & \\
\hline & A & B & $\mathbf{C}$ & Total* & & A & B & $\mathbf{C}$ & Total* & \\
\hline $\begin{array}{l}\text { Cystic Fibrosis [CF] affects which body system? } \\
\text { A: Respiratory and Digestive }\end{array}$ & $\begin{array}{l}100 \\
\mathrm{n}=8\end{array}$ & $\begin{array}{l}100 \\
n=9\end{array}$ & $\begin{array}{l}100 \\
\mathrm{n}=7\end{array}$ & $\begin{array}{l}100 \\
n=24\end{array}$ & 0 & $\begin{array}{l}100 \\
\mathrm{n}=8\end{array}$ & $\begin{array}{l}100 \\
n=9\end{array}$ & $\begin{array}{l}100 \\
\mathrm{n}=7\end{array}$ & $\begin{array}{l}100 \\
n=24\end{array}$ & 0 \\
\hline $\begin{array}{l}\text { Which symptom in an infant or young child might } \\
\text { indicate CF? A: All of the Above }\end{array}$ & 100 & 100 & 100 & 100 & 0 & 100 & 100 & 100 & 100 & 0 \\
\hline $\begin{array}{l}\text { What happens to the mucus glands in a child with } \\
\text { CF? A: The mucus is thick and over produced. }\end{array}$ & 100 & 100 & 100 & 100 & 0 & 100 & 100 & 100 & 100 & 0 \\
\hline $\begin{array}{l}\text { How is the digestive system affected by excess } \\
\text { mucus in CF? A: Mucus clogs the ducts of } \\
\text { pancreas and damages bile ducts in the liver. }\end{array}$ & $\begin{array}{l}75 \\
n=6\end{array}$ & 100 & 100 & $\begin{array}{l}92 \\
n=22\end{array}$ & 11.8 & 100 & 100 & 100 & 100 & 0 \\
\hline How is CF diagnosed? A: Sweat \& Blood Test & $\begin{array}{l}62.5 \\
\mathrm{n}=5\end{array}$ & 100 & $\begin{array}{l}57.1 \\
\mathrm{n}=4\end{array}$ & $\begin{array}{l}75 \\
n=18\end{array}$ & 19.1 & 100 & 100 & $\begin{array}{l}71.4 \\
\mathrm{n}=5\end{array}$ & $\begin{array}{l}91.70 \\
\mathrm{n}=22\end{array}$ & 13.5 \\
\hline $\begin{array}{l}\text { Currently no effective treatment is available to } \\
\text { correct the cause of CF. Doctors can, however, } \\
\text { slow the progression of the disease. Which of } \\
\text { these medications can do this? } \\
\text { A: Bronchodilators, Antibiotics, Decongestants, } \\
\text { Mucolytics. }\end{array}$ & 100 & 100 & 100 & 100 & 0 & 100 & 100 & 100 & 100 & 0 \\
\hline $\begin{array}{l}\text { A defect in a gene that produces the protein cystic } \\
\text { fibrosis transmembrane regulator is the cause of } \\
\text { CF. According to recent research, this } \\
\text { abnormality results in an imbalance of which key } \\
\text { substance in the body? A: Fatty Acids }\end{array}$ & $\begin{array}{l}75 \\
n=6\end{array}$ & $\begin{array}{l}88.90 \\
n=7\end{array}$ & $\begin{array}{l}57.1 \\
\mathrm{n}=4\end{array}$ & $\begin{array}{l}75.00 \\
\mathrm{n}=17\end{array}$ & 12.7 & $\begin{array}{l}87.5 \\
n=7\end{array}$ & 100 & $\begin{array}{l}71.4 \\
\mathrm{n}=5\end{array}$ & $\begin{array}{l}87.50 \\
n=21\end{array}$ & 11.7 \\
\hline $\begin{array}{l}\text { CF is a genetic, or inherited disease. How is CF } \\
\text { passed down through families? A: Both families } \\
\text { are carriers of the CF gene. }\end{array}$ & $\begin{array}{l}75 \\
n=6\end{array}$ & $\begin{array}{l}88.90 \\
n=7\end{array}$ & $\begin{array}{l}85.7 \\
n=6\end{array}$ & $\begin{array}{l}83.30 \\
\mathrm{n}=19\end{array}$ & 11.8 & $\begin{array}{l}62.5 \\
n=5\end{array}$ & 100 & $\begin{array}{l}100 \\
\mathrm{n}=7\end{array}$ & $\begin{array}{l}87.50 \\
n=21\end{array}$ & 17.7 \\
\hline \multirow[t]{2}{*}{$\begin{array}{l}\text { Who is most at risk for Cystic Fibrosis? } \\
\text { A: Caucasians of Northern European descent. }\end{array}$} & 100 & 100 & 100 & 100 & 0 & 100 & 100 & 100 & 100 & 0 \\
\hline & \multicolumn{5}{|c|}{ Pre Total SD: 10.397} & \multicolumn{5}{|c|}{ Post Total SD: 5.3559} \\
\hline
\end{tabular}

$*_{\mathrm{n}}=$ number of participants who responded correctly 


\subsection{Students' perceptions of genomic knowledge after simulation}

Self-perceived knowledge perception data, as seen in Table 3 , showed majority of students $(91.7 \% / \mathrm{n}=22 ; \mathrm{SD}=4.32)$ agreed their understanding of the genetic component of $\mathrm{CF}$ improved as only 2 participants (8.3\%) disagreed. All participants $(n=24)$ agreed their ability to provide information was satisfactory and level of understanding was appropriate to provide effective and efficient nursing care. The majority agreed their critical thinking skills $(n=22)$ with only 2 participants disagreed that their critical thinking skills improved. Twenty-one participants agreed that their clinical judgment about providing genetic information improvement improved (91.7\%) with only 2 participants $(8.3 \%)$ disagreed that their clinical judgment improved.

Table 3. Students' perceptions of their genetic/genomic knowledge after simulation

\begin{tabular}{|c|c|c|c|c|}
\hline Question & $\begin{array}{l}\text { Strongly } \\
\text { Agree }\end{array}$ & Agree & Disagree & SD \\
\hline $\begin{array}{l}\text { Your understanding of the genetic/genomic component of CF improved after this } \\
\text { simulation experience. }\end{array}$ & $\begin{array}{l}41.7 \% \\
(\mathrm{n}=10)\end{array}$ & $\begin{array}{l}50 \% \\
(\mathrm{n}=12)\end{array}$ & $\begin{array}{l}8.3 \% \\
(\mathrm{n}=2)\end{array}$ & 4.32 \\
\hline $\begin{array}{l}\text { Your ability to provide the patient and family with information pertaining to CF } \\
\text { was satisfactory. }\end{array}$ & $\begin{array}{l}37.5 \% \\
(\mathrm{n}=9)\end{array}$ & $\begin{array}{l}62.5 \% \\
(n=15)\end{array}$ & $0 \%$ & 3 \\
\hline $\begin{array}{l}\text { Your level of understanding of CF was appropriate to provide effective and } \\
\text { efficient nursing care with } \\
\text { appropriate nursing interventions. }\end{array}$ & $\begin{array}{l}41.7 \% \\
(n=10)\end{array}$ & $\begin{array}{l}58.3 \% \\
(n=14)\end{array}$ & $0 \%$ & 2 \\
\hline $\begin{array}{l}\text { Your critical thinking skills about providing genetic information to a patient in } \\
\text { this situation have improved. }\end{array}$ & $\begin{array}{l}29.2 \% \\
(\mathrm{n}=7)\end{array}$ & $\begin{array}{l}62.5 \% \\
(\mathrm{n}=15)\end{array}$ & $\begin{array}{l}8.3 \% \\
(\mathrm{n}=2)\end{array}$ & 5.35 \\
\hline $\begin{array}{l}\text { Your clinical judgment about providing genetic information to a patient in this } \\
\text { situation has been improved. }\end{array}$ & $\begin{array}{l}37.5 \% \\
(\mathrm{n}=9)\end{array}$ & $\begin{array}{l}54.2 \% \\
(\mathrm{n}=13)\end{array}$ & $\begin{array}{l}8.3 \% \\
(\mathrm{n}=2)\end{array}$ & 4.55 \\
\hline
\end{tabular}

Note. Option of "strongly disagree" omitted. No participant selection.

\subsection{One open-ended simplified critical incident}

Four super-ordinate themes emerged exploring how the CF simulation scenario enhanced participants' overall ability to integrate genomics included: genomics and nursing $(n=12)$; patient education ( $(n=9)$; patient-nurse relationship $(n=5)$ and teamwork exercise $(n=3)$, as see in the Appendix, Qualitative Data: Themes. This data provided rich descriptive insight of the participants' perception of their genetic literacy of $\mathrm{CF}$ and participation in patient care post simulation experience.

Each major theme had three sub-themes identified, ranging from experience, confidence, applying patient-centered care and education, teaching and communication to group interaction, advocacy and empathy. All the participants expressed how integration of genomics into a simulation was beneficial to their overall learning enhancement while improving their nursing skills, gaining confidence and learned how to confidentially speak about genomics in the nursing field. As one participant stated, "Simulation allowed me to experience what it is like to provide care...to a family affected by a genetic condition" while another stated "The scenario enhanced my overall ability to integrate genetics/genomics into [my] knowledge base of nursing and nursing care". Participants expressed the importance of patient education which facilitates patient outcomes, with statements "I learned to be Published by Sciedu Press able to educate patients on all aspects of genetics" and "I was able to help explain to the parent the way genetics play a role in the diagnosis of CF".

Simulation provides opportunities for students to learn collaborative patient care teamwork while enhancing their communicative skills as professionals. Statements provided by participants included "Preparation before simulation [with the pre-briefing preparatory material] helped me to understand autosomal recessive disorders" and "It was very helpful to have the input of my group mates. They filled in all the gaps I couldn't'. Finally, simulation experiences can instill the concept of advocacy for their patients by obtaining the resources and needed information for the patient and their family. One participant shared that "The scenario offered the opportunity to learn how to teach patients about the genetic information relevant to the disorder".

\section{Discussion}

The timely manner of this study coincides with the release of a new movie entitled Five Feet Apart, whereby two chronically ill teenagers with CF meet in the hospital where they are both being treated. ${ }^{[37]}$ When two individuals with CF meet, it is essential to not spread germs via air-born droplets, thus the technical rule is essentially to keep a minimum of 6 feet ( 2 meters) apart from each other. ${ }^{[38]}$ Five Feet Apart 
will now have a major venue to educate the general populace on this chronic condition and the ramifications of patients and families coping with it. It is obvious that society is becoming more aware and conscious of genetically-based conditions and their affect and effect on those individuals and their families. Nurses must remain committed to being active knowledgeable participants in healthcare hence nurse educators need to be innovatively inspired with merging this core competency. Assimilating a genetic aspect into a SBLE promotes students' genetic knowledge and confidence in providing care and educational information. The positive effect of simulation on patient teaching skills and self-confidence having real clinical implications ${ }^{[39]}$ and the findings in this study further exemplify the enhancement of self-confidence in their nursing skills and patient education process. As participants stated: "Simulation allowed me to experience what it is like to provide care... to a family affected by a genetic condition" and "I found it easier to explain the disease process and how we would implement this knowledge within the treatment plan".

This pilot study has informed the researcher, via the positive findings and students' feedback, that simulation enhances learning outcomes, skill, critical thinking and reasoning, selfconfidence, and communicative capabilities, thus establishing students' success. The findings correlate positively to another study that integrated a genetic component into a simulation. ${ }^{[11]}$ The purposeful inclusion of a genomic simulated case scenario has educational merit. Students overall foundational knowledge base improved post simulation experience, validating that the development of critical thinking, skill performance and medical condition comprehension through simulation is an effective teaching strategy. ${ }^{[14-16]}$ This study affirms that simulation has proven itself to be an effective educational methodology of enhancing student learning outcomes. Improving patient safety and quality of care is an attribute of simulation learning, ${ }^{[40]}$ reaffirmed by this study's findings. Enhancing students' knowledge, skills and attitude towards patient care, through simulation educational experience, will eventually lead to a nurse who can critically think through patient risk assessments to provide competent and proficient patient care.

Integrating a genetically-based condition into a simulation, whereby students are expected to research the condition, engage in patient education, facilitate effective and appropriate nursing care enriches their confidence, skills and knowledge acquisition. Participants overall improvement in the understanding of the $\mathrm{CF}$ genetic component conveys that simulation is a learner-centered pedagogical methodology that ensures students learning outcomes and its effectiveness as a teaching pedagogy. ${ }^{[18,23]}$ Themes of patient education, communication and patient advocacy demonstrated that professional confidence is enhanced via simulation. Professional confidence and experience, clinical reasoning and judgement and reflective practice coalesces into a nurse who can fully engage in the healing-caring process of their patients and family; as confirmed with participants statement of "I definitely feel more confident about my knowledge of CF"; "It gave me the experience [needed] to explain the components of CF" and "It gave me a chance to figure out how to explain genetics in the most understandable and non-intimidating way". As nurses tacitly understand patients' concerns and problems, they can engage in the healing-caring process with tangible and competent participation. ${ }^{[22]}$ Simulation provides experiences that students may never have in the clinical setting but affords them the "opportunity to learn how to teach patients about the genetic information relevant to the disorder" as stated by one of the participants.

Globally, genetically-based conditions are becoming more prominent in healthcare. All healthcare providers are required to be aware of these disorders and be able to provide patient education and care. The WHO has already recognized $\mathrm{CF}$ as an important disease and has requested that all countries revise and modernize their statistics, data gathering and reports on CF cases. ${ }^{[29,30]}$ It is estimated that by 2025 , an increase in the predicted CF patients' survival median rate will go from $12 \%$ to $45 \%$ in most Western countries, with $20 \%$ increase in children and $75 \%$ in adults. ${ }^{[41]}$ Nurses need to be comfortable and confident with this lifelong condition to continue to provide care through-out a patients' lifespan. This study provides further evidence that continued genomic education is required to meet the critical need of this core competency. Continued investigation into actual, perceived and retained genomic knowledge amidst pre-licensure students, their confidence and comfort with championing genetically-based healthcare and their perception and attitude about its integration in nursing curricula is required. ${ }^{[42-44]}$

\section{Limitations}

As this was a purposeful sampling with limited participant involved in only one SON, generalizability cannot be achieved in other schools. In addition, the omittance of demographic data for one specific group is a significant limitation. Being only self-perceived knowledge can be viewed as a limitation as well, as it is not viewed as actual knowledge. An associated risk was a potential breach in confidentiality as surveys were completed in a group setting. Additionally, there is no expectation of privacy, as others in the group may know if participant chose to participate, however, this was addressed in the consent form and there was no identifiable information collected. There was no control group within the study de- 
sign to provide a comparison entity of perceived knowledge. This pilot assessment did demonstrate that genomic integration into a simulation is a creative and innovative format for continued students' comprehension of difficult content matter, though continued exploration into this concept is still warranted.

\section{Conclusion}

This pilot study demonstrated that genomic education can be included into a simulation with positive student learning outcomes. Based on the success of this study, the researcher, with the assistance of the RA, has developed 3 additional evolving simulation scenarios pertaining to this factitious patient that were implemented in Spring 2019. These evolving scenarios were explored with regards to student's genomic learning and perceived knowledge of CF. As geneticallybased health care continues to expand how nurses participate in patient care, the nurse educator needs to stay current and competent to prepare the 21 st Century student as they be- come the future of the nursing workforce. Future research into original and pioneering genomic integration through pedagogical methodologies would diminish the educational gap that persists in nursing education. Further research into pre-licensure genomic literacy is warranted. Given the importance of the genomic era, nursing policy effecting protocols should be explored as to how to further advance the integration of this core competency and continued improvement in patient care of those with genetically-based conditions.

\section{ACKNOWLEDgements}

The author would like to thank all those who participated and Ms. Cait McDonough, Mr. Marvin Sanon, Ms. Cynthia Reyes and Professor Marge Cocozza for their assistance and support in this study. The author received no extramural funding and no commercial financial support in this research.

\section{Conflicts of InTEREST Disclosure}

The author declares that there is no conflict of interest.

\section{REFERENCES}

[1] Calzone K, Kirk M, Tonkin E, et al. The global landscape of nursing and genomics. J of Nurs Scholar. 2018; 50(3): 1-8. PMid:29608246 https://doi.org/10.1111/jnu.12380

[2] Sharoff L. Genetics and Genomics Integration into Undergraduate Nursing Education. J of Nurs Educ and Pract. 2015; 5(4): 13-18. https://doi.org/10.5430/jnep.v5n4p13

[3] Longetti E, Kronk R, Ulmer K, et al. An innovative approach to educating nurses to clinical competence: A randomized controlled trial. Nurse Educ in Pract. 2019; 33: 159-163. PMid:30253916 https://doi.org/10.1016/j.nepr.2018.08.007

[4] Kim J, Park JH, Shin S. Effectiveness of simulation-based nursing education depending on fidelity: a meta-analysis. BMC Med Educ. 2016; 16: 152. PMid:27215280 https://doi.org/10.1186/s1 2909-016-0672-7

[5] Liaw S, Wong L, Chan S, et al. Designing and evaluating an interactive multimedia web-based simulation for developing nurses' competencies in acute nursing care: randomized controlled trial. J of Med Internet Res. 2015; 12: 17(1). PMid:25583029 https: //doi.org/10.2196/jmir. 3853

[6] Jayden J, Smiley R, Alexander M, et al. The NCSBN national simulation study: A longitudinal clinical, randomized, controlled study replacing clinical hours with simulation in prelicensure nursing education. J of Nurs Reg. 2014; 5(2): S3-S40. https://doi . org/10 .1016/S2155-8256(15) 30062-4

[7] Centrella-Nigro A, Blackwell B, Coughlin A, et al. The Effect of Human Patient Simulators on Knowledge and Self-Competence in Graduating Prelicensure Nursing Students. Nurs Educ Persp. 2016; 37(6): 337-339. https://doi.org/10.1097/01. NEP.0000000 000000072

[8] Bryant S, Benson K. Using Simulation to Introduce Nursing Students to Caring for Victims of Elder Abuse and Intimate Part- ner Violence. Nurs Educ Persp. 2015; 36(6): 408-409. https: //doi.org/10.5480/15-1609

[9] Donnelly M, Horsley T, Adams W, et al. Effect of Simulation on Undergraduate Nursing Students' Knowledge of Nursing Ethics Principles. Canadian J of Nurs Res. 2017; 49(4): 153-159. PMid:28948836 https://doi.org/10.1177/0844562117731975

[10] Dame L, Hoebeke R. Effects of a Simulation Exercise on Nursing Students' End-of-Life Care Attitudes. J of Nurs Educ. 2017; 55(12): 701-705. PMid:27893906 https://doi.org/10.3928/ 01484834-20161114-07

[11] Sharoff L. Enhancing Sickle Cell Anemia/Sickle Cell Disease Genetic Understanding through Simulation: A Descriptive Pilot Study. J of Nurs Educ and Pract. 2015; 5(9): 39-48. https ://doi .org/ 10.5430/jnep.v5n9p39

[12] Risling T. Educating the nurses of 2025: Technology trends of the next decade. Nurse Educ in Pract. 2017; 22: 89-92. PMid:28049072 https://doi.org/10.1016/j.nepr.2016.12.007

[13] Lavoie P, Clarke S. Simulation in nursing education. Nursing. 2017; 47(7): 18-20. PMid:28640045 https://doi .org/10.1097/01.N URSE. $0000520520.99696 .9 \mathrm{a}$

[14] Jeffries P, Dreifuerst K, Kardong-Edgren S, et al. Faculty development when initiating simulation programs: Lessons learned from the National Simulation Study. J of Nurs Reg. 2015; 5(4): 17-23. https://doi .org/10.1016/S2155-8256 (15) 30037-5

[15] McIntosh C, Thomas C, Allen R, et al. Using a Combination of Teaching and Learning Strategies and Standardized Patient for a Successful Autism Simulation. Clinical Sim in Nurs. 2015; 11(3): e143-152. https://doi.org/10.1016/j.ecns.2014.11.008

[16] Weatherspoon D, Phillips K, Wyatt T. Effect of Electronic Interactive Simulation on Senior Bachelor of Science in Nursing Students' Critical Thinking and Clinical Judgment Skills. Clinical Sim in Nurs. 2015; 11(2): e126-133. https://doi.org/10.1016/j.ecns.2 014.11 .006 
[17] Mallinson A, McGrath A, Marwick J. The use of an online module to educate and assess staff working in cystic fibrosis care. J of Cystic Fibrosis. 2018; 3(17): 41st European Cystic Fibrosis Conference. Available from: https://www.cysticfibrosisjo urnal .com/article/S1569-1993(18)30533-2/fulltext ht tps://doi.org/10.1016/S1569-1993(18)30533-2

[18] Holt R, Tofil N, Hurst C, et al. Utilizing high-fidelity crucial conversion simulation in genetic counseling training. Amer $\mathrm{J}$ of Med Genetics. 2013; 161A(6): 1273-1277. PMid:23633180 https://do i.org/10.1002/ajmg.a.35952

[19] Roter D, Edelman E, Larson S, et al. Effects of online genetics education on physician assistant interviewing skills. J of Amer Acad of Physician Assistants. 2012; 25(8): 34-41. https ://doi .org/10.1 097/01720610-201208000-00007

[20] LeLacheur S, Straker H, Macri C. Evaluation of a genetics curriculum for physician assistant students. The $\mathrm{J}$ of Physician Assistant Educ. 2007; 18(2): 44-46. https://doi.org/10.1097/013678 95-200718020-00008

[21] Dhar S, Alfort R, Nelson E, et al. Enhancing exposure to genetics and genomics through an innovative medical school curriculum. Genetics in Med. 2012; 14(1): 163-167. PMid:22237446 https://doi.org/10.1038/gim.0b013e31822dd7d4

[22] Benner P, Tanner C, Chesla C. Expertise in Nursing Practice: Caring, Clinical judgement, and ethics. 2nd ed. New York: Spring Publishing; 2009.

[23] Sharoff L. Simulation Preparation, Clinical Judgment and Reflective Process. What is the Connection? J of Cont Educ. 2015; 5(2): 88-101. https://doi.org/10.16899/ctd.49922

[24] American Nurses Association. Essentials of Genetic and Genomic Nursing: Competencies Curricula Guidelines, and Outcome Indicators. 2nd ed. 2008. Available from: https: $/ /$ www google. com/url? sa=t\&rct=j\&q=\&esrc=s\&source=we $\mathrm{b} \& \mathrm{~cd}=1 \& v e d=2$ ahUKEwivj $4 \mathrm{rYgL3kAhWmnOAKHQZ6Ao4QFjAAeg}$ QIARAC\&url=https $\% 3 \mathrm{~A} \% 2 \mathrm{~F} \% 2 \mathrm{~F} w w w$. genome . gov $\% 2 \mathrm{FPages} \% 2 \mathrm{~F}$ Careers\%2FHealthProfessionalEducation\%2Fgeneticsco mpetency pdf\&usg=AOvVaw2Pe8D2qyVpCCcMsJ-uXocz

[25] Sharoff L. Comparison of Perceived Genetic Knowledge of Nurse Educators and Graduate Degree Nursing Students. J of Nurs Educ and Pract. 2017; 7(9): 67-71. https://doi.org/10.5430/jnep .v7n9p67

[26] Calzone K, Jenkins J, Culp S, et al. Introducing a new competency into nursing practice. $\mathrm{J}$ of Nurs Reg. 2014; 5(1): 40-47. https://doi.org/10.1016/S2155-8256(15) 30098-3

[27] Skirton H, O'Connor A, Humphreys A. Nurses' competence in genetics: A mixed method systematic review. J of Adv Nurs. 2012; 68(11): 2387-2398. PMid:22607038 https://doi.org/10.111 $1 / j .1365-2648.2012 .06034 . x$

[28] Tonkin E, Skirton H. The role of genetic/genomic factors in health, illness and care provision. Nursing Standard. 2013; 28(12): 39-46. PMid:24251514 https://doi.org/10.7748/ns2013.11.28.1 2.39.e7550

[29] WHO. Genomic Resource Centre. Genes and human disease. Cystic Fibrosis. Available from: https://www. who.int/genomics/pub lic/geneticdiseases/en/index2.html\#CF
[30] Mirtajani SB, Farnia P, Hassanzad M, et al. Geographical distribution of cystic fibrosis; The past 70 years of data analysis. Biomedical and Biotechnology Res J. 2017; 1(2): 105-112. Available from: http://www.bmbtrj.० rg/article. asp? issn=25889834; year=2017; volume= $1 ;$ issue $=2 ;$ spage $=105 ;$ epage $=112 ;$ aulast=Mirtajani https://doi.org/10.4103/bbrj.bbrj_81_17

[31] Cystic Fibrosis Worldwide. What is Cystic Fibrosis. Available from: https://www.cfww.org/what-is-cystic-fibrosis

[32] Genetic Home Reference. Your Guide to Understanding Genetic Conditions: Cystic Fibrosis. 2019. Available from: https://ghr.nlm. nih.gov/condition/cystic-fibrosis

[33] Cystic Fibrosis.com. What is Cystic Fibrosis. 2017. Available from: http://cysticfibrosis.com

[34] Ratjen F, Bell SC, Rowe SM, et al. Cystic fibrosis. Nature Reviews Disease Primers. 2015; 14(1): 15010. PMid:27189798 https : //doi.org/10.1038/nrdp. 2015.10

[35] Sharoff L. Preliminary Exploration of Simulation Preparation, Clinical Judgment and Reflective Process. J of Cont Med. 2012; 2(3): 141-150.

[36] University of Rochester Medical Center Health Encyclopedia: What Do You Know About Cystic Fibrosis? 2019. Available from: http: //www. urmc.rochester.edu/encyclopedia/document.asp $\mathrm{x}$ ?Content TypeID=40\&Content ID=CysticFibrosisQuiz

[37] Roadshow Films Five Feet Apart. 2019. Available from: https://roadshow.com.au/titles/movies/roadshow/201 9/five-feet-apart

[38] Cystic Fibrosis Foundation. Available from: https: //www.cff.org/Life-With-CF/Caring-for-a-Child-Wit h-CF/Working-With-Your-Childs-School/When-There-s -More-Than-One-Person-With-CF-in-the-Same-School/

[39] Basak R, Demirtas A, Iyigun E. The effect of simulation based education on patient teaching skills of nursing students: A randomized controlled study. J of Prof Nurs. 2019; In press. PMid:31519347 https://doi.org/10.1016/j.profnurs .2019.02.004

[40] Sollid S, Dieckman P, Aase K, et al. Five Topics Health Care Simulation Can Address to Improve Patient Safety: Results from a Consensus Process. J Patient Safety. 2019; 15(2): 111-120.

[41] Blasi F, Elborn J, Palange P. Adults with cystic fibrosis and pulmonologists: new training needed to recruit future specialists. European Resp J. 2019; 53(1): 1802209. PMid:30655450 https: //doi.org/10.1183/13993003.02209-2018

[42] Munroe T, Loerzel V. Assessing nursing students' knowledge of genomic concepts and readiness for use in practice. Nurse Educator. 2016; 41(2): 86-89. PMid:26312820 https://doi.org/10.109 7/NNE. 000000000000210

[43] Sharoff L. Three-Year Assessment of One Pre-Licensure Cohort of Baccalaureate Nursing Students' Attitude, Comfort and Knowledge of Genomics. J of Nurs Educ and Pract. 2017; 7(12): 114-122. https://doi.org/10.5430/jnep.v7n12p114

[44] Sharoff L. Perceived Genetic Knowledge in Pre-Licensure Nursing Students. J of Nurs Educ and Pract. 2017; 7(2): 10-17. https: //doi.org/10.5430/jnep.v7n2p10 